\title{
Kapcsolati hálók és bizalom a vidéki Magyarországon Baranyai kistelepülési polgármesterek társadalmi tőkéje
}

\author{
Networks and trust in the Hungarian countryside \\ Social capital of mayors of small settlements in Baranya
}

\author{
BODOR ÁKOS, GRÜNHUT ZOLTÁN, RAGADICS TAMÁS
}

BODOR Ákos: tudományos munkatárs, MTA Közgazdaság- és Regionális Tudományi Kutatóközpont, Regionális Kutatások Intézete; 7621 Pécs, Papnövelde u. 22.; bodor@rkk.hu; https://orcid.org/0000-0002-5317-8561

GRÜNHUT Zoltán: tudományos munkatárs, MTA Közgazdaság- és Regionális Tudományi Kutatóközpont, Regionális Kutatások Intézete; 7621 Pécs, Papnövelde u. 22.; grunhut@rkk.hu; https://orcid.org/0000-0001-6399-4274

RAGADICS Tamás: egyetemi adjunktus, PTE BTK Szociológia Tanszék; 7624 Pécs, Ifjúság útja 6.; ragadics.tamas@pte.hu; https://orcid.org/0000-0002-0187-3511

KULCSSZAVAK: személyes kapcsolatok; bizalom; informalitás; társadalmi tőke; polgármesterek

ABSZTRAKT: A tanulmány baranyai polgármesterek körében végzett kérdőíves kutatás eredményeit mutatja be. A vizsgálat célja a kistelepülési vezetők társadalmi tőkéjének felmérése volt, személyes kapcsolatrendszerük, valamint az interperszonális és az intézményekbe vetett bizalmuk feltárásával. A kutatás kiindulópontja az az állítás, hogy az eddigi (lakossági) vizsgálatok eredményei szerint Magyarországon a személyek közötti bizalom - európai összehasonlításban - kiegyenlítetlen mintázatú: az embertársak felé mutatott általános bizalom átlag alatti, miközben a családtagokba, közeli ismerősökbe vetett partikuláris bizalom igen magas szintü. Ezen egyenlőtlenség a társas kapcsolatok kialakítását, ápolását, fenntartását és funkcióját is befolyásolja. Többek között ennek következményeként értelmezhető az informális érintkezési mechanizmusok térnyerése. Kutatásunk azt jelzi, hogy a magyar társadalom általános kapcsolatérzékenysége a kistelepülési polgármesterek körében is jellemző. A polgármesterek többsége viszonylag kiterjedt kapcsolati hálóval rendelkezik, miközben az intézményekbe vetett bizalmuk szintje alacsony, a személyközi bizalmuk vonatkozásában pedig egyensúlyhiány figyelhető meg. A kapcsolatok kiterjedtsége kizárólag a partikuláris bizalommal függ össze, vagyis azokra vonatkozik, akik ismerőseikben jobban bíznak. Ez azt jelenti, hogy a kiterjedtebb személyes kapcsolatháló alapja nem az embertársakba vetett bizalom, hanem valamilyen partikuláris kötődés, ami felveti a be- és elzárkózó, klikkszerü együttműködések és az informális érintkezések előnyben részesítésének lehetőségét.

Ákos BODOR: research fellow, Institute for Regional Studies, Centre for Economic and Regional Studies, Hungarian Academy of Sciences; Papnövelde u. 22., H-7621 Pécs, Hungary; bodor@rkk.hu; https://orcid.org/0000-0002-5317-8561

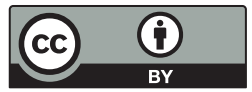


Zoltán GRÜNHUT: research fellow, Institute for Regional Studies, Centre for Economic and Regional Studies, Hungarian Academy of Sciences; Papnövelde u. 22., H-7621 Pécs, Hungary; grunhut@rkk.hu; https://orcid.org/0000-0001-6399-4274

Tamás RAGADICS: assistant professor, Department of Sociology, Faculty of Humanities, University of Pécs; Ifjúság útja 6., H-7624 Pécs, Hungary; ragadics.tamas@pte.hu; https:// orcid.org/0000-0002-0187-3511

KEYWORDS: personal relationships; trust; informality; social capital; mayors

ABSTRACT: The paper examines the social capital of mayors of small settlements in Baranya county, Southern Hungary. It is interested in two components of their social capital: a) the mayors' personal relationships which are strongly tied to their positions; and b) the mayors' trust towards other people and more abstract entities.

Personal relationships and trust are fundamental features of one's social capital. Linkages between the two components are important since trust sheds light on the subject's ability to create and maintain personal relationships, in that those people who have more trust in their fellow human beings can interact more easily and develop their relationships more fully. This theoretical connection is of crucial importance for Hungarian society which appreciates the instrumental value of relationships.

In Hungary, people are aware that personal relationships can make a significant contribution to goal-oriented action. However, this understanding as a cultural pattern raises the question of informality, i.e. the practice of doing and asking favours rather than respecting and applying the more formal and transparent mechanisms. The logic of informality motivates subjects to strive for beneficial relations and to extend their social networks. But these extensive relationships are not based on trust in others in general, they are rather an in-group particularity.

The paper tries to conceptualise this particularity through the lens of social capital, while it aims to empirically identify its foundations as well. What is the reason behind the selection of this particular target group?

Mayors in small settlements are in a social position that makes them central agents in their environment. Most small settlements in Baranya struggle with severe erosion such as infrastructural underdevelopment, persistent emigration, lack of institutions and jobs, weak civil society and civil disengagement, etc. The mayors hold most of the remaining local government competencies, not because they deliberately centralise them, but because there are no relevant agents with whom they can share. Accordingly, in this particular constellation, it is crucial to reveal the temptation of mayors to informality, as their practices can influence the whole atmosphere of local governance and policy-making.

Regarding the findings, it should be briefly noted that most mayors have relatively extensive personal relationships with agents in senior institutional positions; their trust in generalised others is rather low, as is their trust in institutions, while they have relevant trust in their more intimate strong ties. The regression models applied show that there is a positive correlation between the mayors' higher trust in their particular strong ties and the extent of their personal relationships, while the other forms of trust have no influence at all on the same variable.

\section{Bevezetés}

A baranyai kistelepülési polgármesterek társadalmi tőkéjének két aspektusát mutatjuk be: egyrészt az emberekbe és az intézményekbe vetett bizalmukat vizsgáljuk, másrészt a személyes kapcsolatrendszerüknek azt a részét emeljük 
ki, amely közvetlenül összefüggésbe hozható a tisztségükkel. A tanulmány a társadalmitőke-irodalom azon elméleteire támaszkodik (Bourdieu 1986; Coleman 1988; Lin 2000, 2001; Portes 1998), amelyek az egyéni szempontokat vizsgálják elsősorban. Érvelésünk középpontjában a személyes kapcsolatok és a bizalom - mint a társadalmi tőke két alapvető komponense - összefüggése áll. Azt hangsúlyozzuk, hogy az egyén mások irányában mutatott bizalma, annak mértéke, valamint a címzettek körének kiterjedtsége döntően befolyásolja azt, milyen relációkat szándékozik, illetve képes az illető kialakítani és fenntartani. Ezen összefüggés kiemelése azért fontos, mert a magyar társadalomra egyrészt jellemző a kapcsolatok instrumentális jelentőségének túlértékelése (vagyis az a mintakövetés, miszerint a személyes kapcsolatok révén minden könnyebben intézhető el), másrészt ebből fakadóan az informalitás térnyerése, tehát a „kézen-közön" egyezkedések előnyben részesítése a formális ügymenetekkel szemben (Sik 2012). E szemlélet és gyakorlat azt diktálja, hogy sok kapcsolatra érdemes törekedni, amelyeket folyamatosan ápolni és erősíteni kell. Az egyéni hasznokat mindig szem előtt tartó mérlegelés, illetve az ennek tükrében tett és kért szívességek mint a cselekvéseket befolyásoló generatív logikák azonban a társadalom kóros állapotához vezethetnek (korrupció, kirekesztő klikkesedések stb.). Ez utóbbi negatív jelenségekkel a tanulmányunkban nem foglalkozunk, csupán a kapcsolatok iránti érzékenységet és az informalitást kívánjuk bemutatni speciális kontextusban, a baranyai kistelepülési polgármesterek esetét vizsgálva.

Mi indokolja a témaválasztás ilyen fókuszálását? A hazai szakirodalom bőven kínál tanulmányokat olyan kérdésekről, hogy a polgármestereknek milyen szerepkörei vannak a helyi hatalomgyakorlásban, illetve személyiségüknek, egyéni értékrendszerüknek, személyes kvalitásaiknak, elhivatottságuknak, kormányzási stílusuknak miféle hatásai lehetnek a helyi politikára (Tamás 2009, 2014; Táll 1995, 2000). A térségi központoktól távolabb fekvő, számos kihívással (munkahelyek megszünésével, intézmények leépülésével, az aktív lakosság elvándorlásával, a civil élet kiüresedésével, a helyi társadalom szervezetlenségével stb.) küzdő kistelepüléseken mindezen tényezők hatványozottan érvényesek. A helyi hatalomgyakorlás - a még megmaradt, meglehetősen szűk feladatkörök miatt - ugyanis kevésbé differenciálódik ilyen közegben: nincs erős civil társadalom s nincsenek megfelelő intézmények és vállalkozások sem, amelyek a helyi politikai erőteret fontos szereplőkkel gazdagítanák, vagyis egyfajta kompetenciasűrűsödés érvényesül a településvezetőkhöz kötődve. Ebben a helyzetben - amely feltétlenül igaz a baranyai példánkra (Ragadics 2015) - a polgármesterek még inkább véleményvezérei, napirendalkotói, mediátorai és legfőbb döntéshozói (avagy éppen vétószereplői) a helyi politikának. Éppen ezért kell megismernünk, hogy mennyiben jellemző rájuk az informalitás jelensége. Olyan kapcsolatokat indokolt górcső alá venni, amelyek minden érintett településvezető számára instrumentális értékủek. Ezzel magyarázható, hogy a polgármestereknek kizárólag a tisztségükhöz köthető személyes kapcsolatait elemezzük, mégpedig az egyéni bizalommintázattal árnyalva e kapcsolatokat. 


\section{Kistelepülések és polgármesterek: sajátos közeg, sajátos szerepkör}

A magyarországi falvak eltérő mozgáspályáit meghatározó tényezők közül kiemelkedik a lakosság munkaerőpiaci helyzete, valamint a település földrajzi fekvése, illetve a gazdasági-területi struktúrában elfoglalt pozíciója (Beluszky, Sikos T. 2007). „Minél távolabb van egy falu a várostól, és minél kisebb lélekszámú, annál nagyobb a vesztesek száma." (Varga 2005, 59-73.). Az anyagi-jövedelmi helyzet, a kor és a végzettség kemény mutatói mellett más, puhább tényezők is befolyásolják egy kistelepülés fejlődési lehetőségeit. A népesség egyes csoportjainak identitása, a helyi hagyományok, az öröklődő kulturális, viselkedési minták (pl. a munkával és együttmüködéssel kapcsolatos tradíciók), a helyi elit kvalitása, valamint a rendelkezésre álló és aktivizálható társas kapcsolatok egyaránt hatással vannak a falu jövőjére (Bódi, Bőhm 2000; Ludescher 2010; Váradi 2008).

A gazdasági központoktól távolabb fekvő vidéki térségekben (Magyarországon és Európa rurális területein egyaránt) előrehaladt a társadalmi erózió. Jelentős az elvándorlás, meggyengülnek a hagyományos helyi kapcsolatok alapját, a társadalmi tőke bázisát jelentő tényezők (pl. munkahelyek, munkaalkalmak, intézmények és szolgáltatások). A lakosság nagy hányada él az országos átlagnál alacsonyabb életszínvonalon. Általában jelentős a központi települések felé orientálódók aránya is (a szolgáltatások igénybevétele, a fogyasztás és a térhasználat szempontjából). E folyamatok aláássák a helyi társadalmak szervezettségét, gyengítik érdekérvényesítő képességét. Az elvándorlók révén esetlegesen bevonható kapcsolatok is kiaknázatlanok maradnak a lokálisan elérhető erőforrások hiányában.

A helyi intézményrendszer állapota nemcsak a népesség ellátása szempontjából meghatározó, hanem azért is, mivel a lokális intézményekben alkalmazottak közül kerülnek ki a települések véleményvezérei, kulcsszereplői. A vállalkozók és a nagyobb gazdálkodók rétege mellett ők alkotják a helyi elitet, illetve a terület- és településfejlesztési forrásokat elérő, azokat felhasználó ún. projektosztályt a falusi társadalmakban (Kovách 2013). Az intézmények leépülése és a piaci szereplők kivonulása így több szempontból is a fontos ágensek csökkenését eredményezi. A polgármester személye - funkcióiból következően - már korábban is jelentős volt a település fejlődése szempontjából (Bódi, Bőhm 2000; Pálné Kovács 2008), ám a helyi hatalmi helyzet átalakulása, vagyis a lokális politikai erőtér kiüresedése miatt még inkább azzá válik.

Tanulmányunk a helyi kulcsszereplők jelentőségét vizsgálja a helyi társadalmakban (Csurgó 2011; Váradi 2008). A falu fejlesztési lehetőségeiről a településen élők szolgálhatnak hiteles információkkal, munkájuk, napi aktivitásuk során rendszeres a kapcsolatuk a település lakóival, és feladataik közé tartozik a helyi közösség érdekeinek képviselete, a lokális konfliktusok kezelése. A falusi társadalom szervezettségét - a nagyobb településekhez képest sokkal inkább - a fontos helyi pozíciókat betöltő egyének személyes kvalitásai, 
rátermettsége, döntései és szándékai befolyásolják alapvetően (Ragadics 2010). Minél kisebb egy település, annál kevesebb a lokális kulcspozíciók száma és annál nagyobb a döntéshozók szerepe és felelőssége. A települési vezetőknek és a helyi társadalom más kiemelt szereplőinek (vállalkozók, pedagógusok, civilek, egyházi szereplők stb.) speciális helyzete összefüggésben van a vidéki térségek migrációs trendjeivel. E kulcsszereplők jelentőségét nemcsak a kvalifikált népesség elvándorlása miatt fellépő szakemberhiány alapozza meg, hanem a helybeli lakosság munkaerőpiaci és közösségi passzivitása is. Egy dél-baranyai térségben folytatott kvalitatív vizsgálat (Ragadics 2015) - az anyagi források beszükülésével és az interakciós lehetőségek visszaszorulásával összefüggésben - gyengülő szolidaritásról, az összetartás és együttműködés hiányáról számolt be. Pesszimizmus, motiválatlanság, kiszolgáltatottság és az öngondoskodási készségek leépülése jellemzi a vidéki térségek társadalmait (Bognár, Csizmady 2005). A kis társadalmi tőkével rendelkező, paternalista viszonyok között szocializálódó népesség sorsának alakulása szempontjából felértékelődik a helyi kulcsszereplők kapcsolatrendszere.

A polgármestereket demokratikus választások keretei között a helyi közösség bízza meg érdekei képviseletével, így a kistelepüléseken a legnagyobb helyi hatalom, legitimitás és presztízs kétségkívül ehhez a tisztséghez kapcsolható (Letenyei 2005). Ezt a pozíciót az önkormányzati autonómia is erősíti (Pálné Kovács 2008). Noha 2011 után jelentősen átalakult a települési önkormányzatok pozíciója és finanszírozása, számottevően csökkent függetlenségük mértéke és intézményfenntartó szerepük, ám megmaradt, sőt a közfoglalkoztatás révén tovább erősödött jelentőségük a hátrányos helyzetű rétegek ellátása terén. A polgármester személye, elkötelezettsége, képességei, munkabírása, kapcsolatrendszere ezért továbbra is meghatározó a falu sorsa, fejlődése szempontjából, így a kistelepülések vezetőinek társadalmi tőkéjével foglalkozó vizsgálatok kiemelten fontosak.

\section{A társadalmi tőke fundamentumai: kapcsolatok és bizalom}

A társadalmi tőke viszonylag új, de nem előzmények nélküli elméleti konstrukciónak tekinthető. Bourdieu (1986) a gazdasági, társadalmi és kulturális tőketípusok tárgyalása során azt hangsúlyozza, hogy a társadalmi tér strukturálisan differenciált, alapvető kódok/elvek (nomos) szerint mezőkre (champs) oszlik, amelyeken különféle tétekért (illusio) folyik a versengés az ágensek között, hierarchikus alá-fölérendeltségi viszonyokba (doxa) rendezett formában. E versengések során az ágensek a strukturális kényszerek által alakított ideáikra és gyakorlataikra (habitus), illetve a társadalmi státuszuk által meghatározott töketényezőikre (capital) támaszkodnak. A tétekért folyó versengésben az átváltható tőketényezők egyike a társadalmi tóke, amely Bourdieu szerint az egyén 
kapcsolatrendszereit öleli fel. Az érvelés alapján, a marxi logikát követve, valamennyi tőketípus birtoklása egyúttal mások ugyanazon tőkéktől való megfosztottságát jelenti, ellenkező esetben, vagyis akkor, ha azokhoz bárki, bármikor hozzáférne, az adott tőke elveszítené konverziós értékét. Ebből kifolyólag a tőkebirtoklás minduntalan újratermeli a társadalmi egyenlőtlenségeket. A tét elérésében sikeresebb, tehát magasabb státuszú egyének mindezek miatt érdekeltek saját kapcsolatrendszereik jelentőségének megőrzésében, amelyeket további értékes nexusok bevonásával, illetve az értéktelenek kirekesztésével érhetnek el.

Mikor nevezhető egy kapcsolat értékesnek? E ponton az okfejtést indokolt kibővíteni Granovetter (1983) erős és gyenge kötésekről szóló elméletével. Az érvelés szerint erős kötés az intenzív és intim, vérségi és érzelmi alapú (családi, rokoni, szerelmi, szoros baráti) kapcsolatokat jellemzi, amelyek egyfajta „biztonságos szigetek" a nexusok tengerében. Ezekhez képest gyenge kötések a kevésbé intenzív és intim, többnyire még az érintettek közötti kölcsönös identitási és csoportazonossági ismérveket is nélkülöző relációk, ahol az egyének távoli ismerősökként gondolnak egymásra. Granovetter a gyenge kötések funkcióját látja lényegesebbnek az egyén különféle tétekért (elsősorban a magasabb jövedelmü és presztízsű, nagyobb hatalmat és önállóságot biztosító foglalkozások megszerzéséért) folytatott versengéseinek sikere szempontjából. Miért? Mert a gyenge kötések szélesítik és gyorsítják az információáramlást, többféle ismertséghez, szélesebb és összetettebb társas közegekhez lehet hozzáférni általuk, miközben komplexebb impulzusokat küldenek az egyén irányába, amelyekre a szubjektum (cselekvő alany) kevésbé tud rutinszerüen, reflexivitás, adaptáció és önfejlesztés nélkül reagálni.

Lin (1991) koncepciója a társadalmi erőforrások és a társadalmi cselekvések összefüggését foglalja elméleti keretbe. Nála is a célorientált törekvés, az ún. státuszelérés az egyéni cselekvések motivációja, amely erőforrásokért folyó versengésként értelmezhető. Ezen erőforrások olyan szimbólumok és tárgyak, amelyeket egy társadalmi rendszerben közös megegyezésen alapulóan hasznosnak tekintenek (legtöbbször a gazdagság és a hatalom különböző komponenseiről van szó). Lin a státuszelérés kapcsán két cselekvéstípust különböztet meg: az expresszív forma az értékes erőforrás megtartására, míg az instrumentális azok megszerzésére törekszik. Előbbi cselekvéstípus a kizárási gyakorlat okán homofilikus interakciókhoz vezet, míg az utóbbi újabb értékes kapcsolatok saját hálózatba való bevonását jelenti, tehát heterofilikus érintkezéseket ösztönöz. Mindez megfeleltethető a granovetteri erős és gyenge kötések megkülönböztetésnek, amennyiben a homofilikus interakciók zártabb és intimebb csoportközeget feltételeznek, míg a heterofilikusak extenzívebb és lazább társas érintkezési kontextusokat.

A három szerző okfejtésére épülő gondolatmenetből két jelentős következtetést lehet levonni. Egyfelől a személyes kapcsolatoknak instrumentális szerepe van a célorientált egyéni cselekvések sikeressége szempontjából. Más- 
felől - Bourdieu alapján talán kevésbé, Granovetter és Lin elmélete tükrében ugyanakkor biztosan - állítható, hogy a kiterjedtebb, tehát számosságát tekintve szélesebb és heterofilikusabb egyéni kapcsolatrendszer jobban képes hozzájárulni a szubjektum cselekvéseinek eredményességéhez.

Ugyanakkor az egyén kapcsolatainak kialakítását és fenntartását jelentősen befolyásolja, hogy az illető mennyiben képes mások iránt bizalmat előlegezni; vagyis milyen kiterjedésủ e szubjektív bizalomérzet mértéke és címzettjeinek köre. A személyes kapcsolatokhoz hasonlóan ezért számos társadalmitőke-koncepciónak a bizalom is alapvető komponense (Fukuyama 1997a; Putnam 2000). A különböző bizalomelméletek elsősorban a nyolcvanas évtized végén kezdtek kibontakozni a szociológia és politikatudomány területén (fontos monográfiák: Barber 1983; Coleman 1990; Fukuyama 1997b; Hardin 2002, 2006; Seligman 2000; Uslaner 2002). Javarészt középszintű elméletekről van szó, amelyek egyrészt szervesen kapcsolódnak integrációs és modernizációs tárgyú nagy társadalomelméletekhez, másrészt azonban figyelemmel vannak egyéni adottságokra, pszichológiai aspektusokra és személyes erőforrásokra is a szubjektív bizalomérzet megalapozása és igazolása vonatkozásában (Giddens 1990; Luhmann 1979; Sztompka 1999). Rendszerint abból a feltételezésből indulnak ki e teóriák, hogy a párhuzamos globalizáció és lokalizáció dinamizáló hatásai következtében a korábban stabil, de statikus, intézményesült formát öltő (hagyományos) minták integrációs szerepe folyamatosan csökken, ami bizonytalanságokkal telíti a mindennapi interszubjektív és szubjektív interakciókat (Giddens 1990). Egyrészt a technológiai és informatikai fejlődés, az elszemélytelenedés (amely az automatizáció, robotizáció és digitalizáció formájában hat), továbbá az információáramlás, másrészt a férfi és női szerepek megváltozása, a különféle pozíciók átértékelődése, a társadalmi státuszok és társas érintkezések (család, házasság, szerelmi és baráti kapcsolatok, gyereknevelés stb.) újraértelmeződése, valamint a szexualitás és a test jelentésének átalakulása következtében a korábbi szimbólumok referenciaértéke meggyengül (Beck 2003). Új típusú függőségek alakulnak ki (a technológiáknak, az interpretált információknak, a szakértői kapacitásoknak való egyéni kiszolgáltatottság), miközben az egységesítő logikák és szemantikák halványulása teret ad a szubjektivitás kibontakozásának. Mindez korábban nem ismert kockázatokkal jár, amelyek kezelése az egyénre hárul - rutinideák és -praxisok alkalmazása nélkül, reflexió által. E kockázatok miatt válik jelentőssé a bizalom, amelynek interperszonális formája az interszubjektív, míg az absztraktabb entitások irányába mutatott bizalom a szubjektív interakciókat teszi lehetővé (Sztompka 1999).

A bizalom e két főbb típusán belül további fajták különíthetőek el. Fukuyama (1997b) a személyközi változat esetében az ún. bizalomrádiuszok mentén tesz különbséget: a legszűkebb kör, vagyis a családtagok és közeli barátok iránti bizalom adja az egyik végpontot, ezt partikuláris interperszonális bizalomnak nevezi a szakirodalom. A legtágabb kör pedig - mindenféle megkülönböztetés nélkül - az embertársak felé kifejezett bizalmat jelenti, ami általánosított interperszonális bizalomként ismert. Amíg a partikuláris bizalomnak jelentős szerepe van az én 
autopoietikus (narratív és performatív) megteremtése, illetve a szocializáció során elsajátított, reflexív és kritikai módon felülvizsgált individuális ideák és praxisok alkalmazása szempontjából, addig az általánosított bizalom inkább a társadalmi integráció, a kohézió előmozdítását segíti.

A szűkebb körben érvényesülő partikuláris bizalom az erős kötésekkel és a homofilikus interakciókkal, míg az embertársak iránt kifejezett általánosított bizalom a gyenge kötésekkel és a heterofilikus társas érintkezésekkel áll elméleti összefüggésben. Nem szabad azonban elfelejteni, hogy az interperszonális bizalom belső mintázata többféle formát vehet fel, ezért a fenti összefüggést árnyalni szükséges. Alacsony partikuláris és általánosított bizalom elsősorban azokra a szubjektumokra jellemző, akik mindenféle társas érintkezéstől elzárkóznak. Viszonylag kevés ilyen egyén lehet egy közösségben, ugyanakkor nem zárható ki ez az eset. Ezzel szemben hibás feltételezés, ha valakinek az alacsony partikuláris bizalma magas általánosított bizalommal párosul, hiszen senki sem képes embertársai iránt általában bizalommal lenni, ha egyáltalán nem képes erős kötésű kapcsolatot kialakítani. A mindkét típus magas volta a legkedvezőbb eshetőség az egyén és a társadalom szempontjából. A magas partikuláris és az alacsony általánosított bizalom együttes megjelenése ugyanakkor patológiákra utalhat.

Az elméleti alternatívák figyelembevétele különösen az utóbbi változat miatt fontos a jelen érvelés és problémafelvetés szempontjából. Európai összehasonlításban Magyarországon - a lakossági vizsgálatok egybehangzó eredményei szerint - az interperszonális bizalom belső mintázata erősen kiegyenlítetlen: az általánosított bizalom átlag alatti eredményeket mutat, miközben a partikuláris bizalom igen magas (Bodor, Grünhut, Horeczki 2014; Hajdu 2012; Tóth 2009). Mindez több volt szocialista ország példáján is megfigyelhető (Giczi, Sik 2009). Ez az egyensúlyhiány két kóros állapotot válthat ki: amorális familizmust (Banfield 1958) és informalitást (Giczi, Sik 2009). Előbbi azokra a társadalmakra jellemző, ahol a családtagokba vetett bizalom jelentősen meghaladja nemcsak az embertársak, de még a közeli barátok, ismerősök iránti bizalom szintjét is (pl. Lengyelország, Románia). Informalitás azokat az országokat jellemzi, ahol különösen erős a személyes kapcsolatokba vetett bizalom, miközben az ismeretlen embertársak iránt bizalmatlanok az egyének. Magyarország ez utóbbi csoportba sorolható, amit Sik $(2012,166$.$) a magyar társadalom kapcsolatérzékenységével$ magyarázott. „Egy ilyen világban élni azt jelenti, hogy mindenki tudja, hogy a kapcsolatok fontosak, s ezért azokat ápolni érdemes (a haszon elvének megfelelően), hogy mások is ezt teszik, s ezért a kapcsolatokat ápolni kötelesség (a közösségbe tartozás elvének megfelelően), s hogy ez így természetes is (kulturális hatás)." Kapcsolatérzékeny kultúrákban tehát az intézmények müködését is erősen áthatják a partikuláris bizalom mentén szerveződő informális érintkezések. A személytelen, formális szervezetközi relációk vizsgálata helyett ezért sok esetben beszédesebb az intézmények képviseletében eljárók személyes nexusainak feltárása. 
Mindezek tükrében a Bourdieu, Granovetter és Lin gondolatmenetéből leszűrt két következtetés - miszerint a kapcsolatoknak egyrészt instrumentális jelentőségük van, másrészt a kiterjedt, heterofilikus kapcsolathálózat hatékonyabban járul hozzá a célorientált egyéni cselekvések eredményességéhez - úgy árnyalható a bizalom irodalma alapján, hogy általánosított bizalom hiányában, pusztán partikuláris bizalomra alapozva e személyes kapcsolatok nem jelentenek többet, mint egocentrikus nézőpontból értékelt, haszonmaximalizálásra alkalmazható eszközöket.

Figyelemmel a patologikus tendenciát hangsúlyozó vizsgálatok eredményeire, a dolgozat első hipotézise a következő: a kistelepülési polgármesterek körében a tisztséghez köthetö személyes kapcsolathálózat kiterjedtsége nem mutat összefüggést az általánositott bizalommal, ugyanakkor a partikuláris bizalommal igen, mégpedig pozitív irányút. Az egyének tehát törekednek minél több kapcsolat kialakítására, de nem azért, mert embertársaik iránt alapvetően bizalommal vannak, velük általában azonosulnak, hanem inkább azért, mert a több kapcsolat több informálisan igénybe vehető szívességgel kecsegtet. Vagyis a kiterjedtebb kapcsolathálózat nem jelent igazán heterofilikus érintkezéseket: az egyén szűk körbe igyekszik vonzani nexusait. Ezt az összefüggést az absztraktabb entitások iránti bizalommal is alátámasztani igyekszik a dolgozat. E bizalomformához is eltérő típusok sorolhatóak. A pozíciós bizalomtól az intézményin át az ún. rendszerbizalomig bizonyos körök különíthetők el, amelyek az adott entitások absztrakt jellegére utalnak. Pozíciós bizalom esetében az egyén jeleníti meg az intézményt (pl. orvos, postás stb.). Mivel ezekkel az egyénekkel interszubjektív viszony alakítható ki, így nemcsak a megjelenített intézmény, de maga az azt megjelenítő egyén iránti bizalom is érvényesül.

Az intézményi bizalom esetében már sokkal inkább szervezetekről (pl. parlament, rendőrség stb.) és eljárásokról (minőségbiztosítás) van szó, amelyekkel, mint tárgyiasult dolgokkal, szubjektív interakcióban áll az egyén. A rendszerbizalom az utóbbihoz képest is általánosabb: átfogó rezsimek (pl. demokrácia, emberi jogok stb.) iránti bizalom tartozik e típusba. Lakossági vizsgálatok szerint (Boda, Medve-Bálint 2012, 2013; Bodor, Grünhut, Horeczki 2014) a magyar társadalom intézményi bizalma európai összehasonlításban alacsonynak nevezhető. A második hipotézisünk: a kistelepülési polgármesterek körében a tisztséghez kötheto” személyes kapcsolathálózat kiterjedtsége negatív összefüggést mutat az intézményi bizalommal. Éppen azért van szükség a személyes ismerősök informális közreműködésére, mert a formális intézményi viszonyokban nem lehet megbízni.

\section{Adatok, módszerek, eredmények}

Kérdőíves felmérésünkben ${ }^{1}$ a vizsgálat alapsokaságát a Baranya megyei 1000 fó alatti települések (összesen 260 település) polgármesterei jelentették. Rétegzett 
mintavétellel 170 települést/polgármestert választottunk ki, ${ }^{2}$ közülük 163 esetében bizonyult sikeresnek a megkeresés, ami kifejezetten jó aránynak számít.

Az elemzés első részében leíró módszerekkel mutatjuk be a személyes kapcsolathálózat, valamint a bizalom mérésére alkalmazott változók eredményeit. A standard kérdések használata miatt a bizalom esetében lehetőség van az adatok más vizsgálatokkal való összehasonlítására is. A két társadalmitőke-komponens összefüggéseit regressziós modellekkel is vizsgáljuk.

\section{A kapcsolatok számossága}

Kérdőívünk a polgármesterek kapcsolati erőforrásait egy pozíciógenerátor jellegű kérdéssorral térképezte fel. A hagyományos pozíciógenerátor (Kmetty, Koltai 2015; Lin, Dumin 1986) azt méri, hogy a megkérdezettnek milyen munkakörökben dolgozó emberekkel van kapcsolata. Ezek a lakossági felmérések különféle foglalkozások formájában operacionalizálják az elérhető társadalmi erőforrásokat. Jelen vizsgálat speciális célcsoportja miatt, a pozíciógenerátor logikájára építve, saját kategóriákat dolgoztunk ki. Míg a hagyományos pozíciógenerátoros kutatások a foglalkozási hierarchiában különböző helyet elfoglaló munkakörök elérését vizsgálják annak érdekében, hogy felmérjék a magas, illetve alacsony társadalmi státuszú kapcsolatokat, addig ez a kérdőív kifejezetten a magas státuszú pozíciók elérésére koncentrált. A polgármestereknek feltett kérdések a következők voltak:

Kérem, mondja meg, hogy a felsorolt kategóriákba tartozók közül van-e Önnek személyes ismeröse! Ha igen, hány személy?

- Politika - vezetö beosztású politikus (pl. miniszter, megyei közgyülés elnöke, pártvezető, országgyülési képviselő);

- Közigazgatás - vezető beosztású közigazgatási szakember (pl. minisztériumi föosztályvezetö, megyei jegyzö/kormányhivatal-vezetö, városi jegyzö);

- Szakigazgatás - szakhivatal vezető beosztású szakembere (pl. vezető bíró, vezető ügyész, vezetö tisztiorvos);

- Projekt, pályázat - fejlesztési ügynökség/társaság vezető beosztású szakembere;

- Szakmai érdekképviselet - vezetö (pl. kamara vezetöje, Töosz);

- Pénzintézet - bankfiók vezetője, takarékszövetkezeti vagy hitelintézeti vezetö;

- Nagyvállalat - nagyvállalat vezetője, topmenedzsere, tulajdonosa;

- Egyetem, kutatás - kutatóintézeti kutató, egyetemi tanár, professzor.

A polgármesterek számára értékes kapcsolatok listájának összeállítása volt a cél. Olyan magas presztízsű foglalkozási kategóriákat neveztünk meg, amelyek ténylegesen erőforrást jelenthetnek a településvezetői feladatok ellátása során. ${ }^{3}$

A kategóriák között jelentős eltérések vannak, és az egyes kategóriákon belül is a polgármesterek válaszai számottevő különbségeket mutatnak (1. táblázat). Az átlag alapján a legtöbb személyes ismerősről a politikai szektor esetében számoltak be a megkérdezettek. A válaszadók között volt olyan polgármester, 
1. táblázat: A személyes kapcsolatok átlaga, szórása, minimumai és maximumai kategóriánként $(\mathrm{N}=137)^{4}$

Mean values, standard deviation, minimum and maximum values of personal relations according to categories $(N=137)$

\begin{tabular}{lrcccc}
\hline Hány személyes ismeröse van... & Átlag & Medián & Minimum & Maximum & Szórás \\
\hline ... politika & 11,6 & 5 & 0 & 101 & 16,5 \\
... közigazgatás & 9,0 & 4 & 0 & 75 & 12,2 \\
...szakigazgatás & 3,2 & 2 & 0 & 24 & 4,2 \\
... projekt, pályázat & 3,8 & 2 & 0 & 40 & 5,6 \\
... szakmai érdekképviselet & 3,0 & 1 & 0 & 34 & 4,6 \\
...pénzintézet & 2,8 & 2 & 0 & 16 & 2,9 \\
...nagyvállalat & 6,1 & 2 & 0 & 82 & 10,8 \\
...egyetem, kutatás & 3,7 & 1 & 0 & 65 & 7,8 \\
\hline
\end{tabular}

Forrás: saját adatfelvétel.

aki 101 vezető beosztású politikust tart személyes ismerősének, míg mások úgy nyilatkoztak, hogy egyetlen e szektorhoz köthető kapcsolatuk sincs, így a szórás értéke igen magas. (Az átlag 11,6, míg a medián értéke 5, vagyis a polgármesterek felének ennél kevesebb vezető beosztású politikus ismerőse van.) A kapcsolatok száma szerint a politikai szektort a közigazgatás és a nagyvállalatok felső vezetőivel való kapcsolatok követik. Összeadva az egyes kategóriákban említett személyes ismerősök számát, a polgármestereknek átlagosan 43,3 kapcsolatuk van (medián=29,0, a szórás 44,6).

\section{A kapcsolatok diverzitása}

A kapcsolathálózati diverzitás azt mutatja, hogy a polgármestereknek milyen sokrétű a kapcsolatrendszere, azaz a nyolc kategóriatípus közül hány esetben említenek legalább egy személyes ismerőst (2. táblázat).

2. táblázat: Személyes ismerősök aránya kapcsolati típusonként (\%,N=137)

Personal relations in the different categories (mayors have/have no relations, \%) $(N=137)$

\begin{tabular}{lcc}
\hline \multicolumn{1}{c}{ Kategória } & Van személyes ismeröse & Nincs személyes ismeröse \\
\hline Politika & 82,5 & 17,5 \\
Közigazgatás & 89,8 & 10,2 \\
Szakigazgatás & 70,1 & 29,9 \\
Projekt, pályázat & 75,9 & 24,1 \\
Szakmai érdekképviselet & 38,7 & 61,3 \\
Pénzintézet & 87,6 & 12,4 \\
Nagyvállalat & 69,3 & 30,7 \\
Egyetem, kutatás & 56,9 & 43,1 \\
\hline
\end{tabular}

Forrás: saját adatfelvétel. 
3. táblázat: A kapcsolati diverzitás megoszlása ( $\mathrm{N}=137)$

The diversity of personal relations according to categories $(N=137)$

\begin{tabular}{lcc}
\hline \multicolumn{1}{c}{ Kategória } & $\%$ & Kumulatív \% \\
\hline Egyetlen kapcsolati típusban sincs személyes ismerőse & 2,2 & 2,2 \\
Egy kapcsolati típusban van személyes ismerőse & 4,4 & 6,6 \\
Kettő kapcsolati típusban van személyes ismerőse & 2,9 & 9,5 \\
Három kapcsolati típusban van személyes ismerőse & 2,2 & 11,7 \\
Négy kapcsolati típusban van személyes ismerőse & 8,0 & 19,7 \\
Öt kapcsolati típusban van személyes ismerőse & 13,1 & 32,8 \\
Hat kapcsolati típusban van személyes ismerőse & 19,0 & 51,8 \\
Hét kapcsolati típusban van személyes ismerőse & 20,4 & 72,3 \\
Nyolc kapcsolati típusban van személyes ismerőse & 27,7 & 100,0 \\
\hline Összesen & 100,0 & 100,0 \\
\hline
\end{tabular}

Forrás: saját adatfelvétel.

A vizsgált kapcsolati típusok közül legnagyobb arányban a közigazgatásban (89,8\%), majd a pénzintézeteknél $(87,6 \%)$, a politikában (82,5\%), negyedikként pedig a projektek világában $(75,9 \%)$ rendelkeznek a polgármesterek vezető beosztású személyes ismerőssel.

A kapcsolati diverzitás összesített megoszlását a 3. táblázat mutatja: a megkérdezett településvezetők kicsit több mint fele legfeljebb hat kapcsolattípusban rendelkezik ismerősökkel, míg valamivel több mint 27\%-uk mindegyik kategóriában.

\section{Bizalom - általánosított interperszonális bizalom}

Az általánosított bizalom vizsgálatához három kérdést tartalmazott a kérdoív:

- Általánosságban Ön mit mondana? A legtöbb emberben meg lehet bízni, vagy inkább azt, hogy nem lehetünk elég óvatosak az emberi kapcsolatokban?

- Gondolja, hogy a legtöbb ember megpróbálná kihasználni Önt, ha alkalma nyilna rá, vagy igyekeznének tisztességesek lenni?

- Ön szerint az emberek inkább csak magukkal törődnek, vagy általában segito”készek? ${ }^{5}$

A válaszlehetőségeket 0-tól 10-ig terjedő skálán adhatták meg az interjúalanyok, ahol az első kérdés esetében a 0 azt jelenti, hogy „Nem lehetünk elég óvatosak”, míg a 10 azt, hogy „A legtöbb ember megbízható”. A második kérdés esetében a 0 azt jelenti, hogy „A legtöbb ember megpróbálná kihasználni”, míg a 10 azt, hogy „A legtöbb ember igyekezne tisztességes lenni”. A harmadik esetében pedig a 0 jelentése az, hogy „Az emberek csak magukkal törődnek”, míg a 10 azt, hogy „Az emberek általában segítőészek”.

A 4. táblázatban szerepelnek a polgármesterek válaszai mellett a European Social Survey ${ }^{6}$ 8. hullámának 2016-os magyarországi lakossági adatfelvételéből származó eredményei is. Az adatok alapján a polgármesterek átlagos általánosí- 
4. táblázat: Az általánosított bizalom változóinak átlaga és szórása a polgármesterek, illetve az ESS mintáján

Mean values and standard deviations of general trust among mayors and in the Hungarian society

\begin{tabular}{|c|c|c|c|c|}
\hline \multirow[t]{2}{*}{ Kérdések } & \multicolumn{2}{|c|}{$\begin{array}{l}\text { Polgármesterek } \\
\qquad(\mathrm{N}=137)\end{array}$} & \multicolumn{2}{|c|}{$\begin{array}{c}\text { Magyar lakosság } \\
(\mathrm{N}=1614)\end{array}$} \\
\hline & Átlag & Szórás & Átlag & Szórás \\
\hline $\begin{array}{l}\text { Általánosságban Ön mit mondana? A legtöbb emberben meg } \\
\text { lehet bízni, vagy inkább azt, hogy nem lehetünk elég óvatosak } \\
\text { az emberi kapcsolatokban? }\end{array}$ & 5,4 & 2,5 & 4,5 & 2,3 \\
\hline $\begin{array}{l}\text { Gondolja, hogy a legtöbb ember megpróbálná kihasználni Önt, } \\
\text { ha alkalma nyílna rá, vagy igyekeznének tisztességesek lenni? }\end{array}$ & 5,2 & 2,4 & 4,8 & 2,1 \\
\hline $\begin{array}{l}\text { Ön szerint az emberek inkább csak magukkal törődnek, vagy } \\
\text { általában segítőkészek? }\end{array}$ & 5,0 & 2,2 & 4,6 & 2,2 \\
\hline
\end{tabular}

Forrás: saját adatfelvétel, illetve az ESS 8. hulláma.

tott bizalma mindhárom kérdés esetében némileg magasabb értéket mutat, mint a magyar lakossági átlag. A legjelentősebb különbség az első kérdésnél figyelhető meg. A szórás mutatói mindkét mintában hasonlóak. Az ESS átlagértékeit tekintve a magyar lakosság általános bizalma átlag alattinak tekinthető, az európai sorrend alsó felében helyezkedik el.7 Ehhez képest a polgármesterek bizalma valamivel magasabb, ugyanakkor ezek az átlagértékek is inkább a szűk bizalmi rádiusz jeleként értékelhetők.

\section{Bizalom - partikuláris interperszonális bizalom}

A partikuláris bizalom méréséhez is a nemzetközi kutatási gyakorlatban bevett kérdéseket tartalmazott a kérdőív:

Mennyire bizik Ön

- a családjában?

- a barátaiban?

- a szomszédjaiban?

- azokban az emberekben, akiket személyesen ismer? ${ }^{8}$

A válaszlehetőségeket itt is 0-tól 10-ig terjedő skálán adhatta meg a válaszadó, ahol a 0 azt jelenti, hogy egyáltalán nem bízik meg bennük, míg a 10 azt, hogy teljesen megbízik bennük.

A válaszadók leginkább a családjukban bíznak meg, döntő többségük a skála maximális értékét jelölve meg (5. táblázat). (Lakossági összehasonlításhoz sajnos nem áll rendelkezésre olyan jó lehetőség, mint az általánosított bizalom esetében. A World Values Survey (WVS) kérdőívében három változó szerepel saját vizsgálatunk kérdései közül, azonban négyfokú skálán mérve, továbbá Magyarország esetében az utolsó elérhető adatforrás 2009-ből származik.") 
5. táblázat: A partikuláris bizalom változóinak átlaga és szórása ( $\mathrm{N}=137)$

Mean values and standard deviations of particular trust among mayors (N=137)

\begin{tabular}{lcc}
\hline \multicolumn{1}{c}{ Mennyire bízik Ön } & Átlag & Szórás \\
\hline ... a családjában & 9,7 & 0,9 \\
... a barátaiban & 8,8 & 1,6 \\
... a szomszédjaiban & 7,0 & 2,4 \\
... azokban az emberekben, akiket szermélyesen ismer? & 6,7 & 1,7 \\
\hline
\end{tabular}

Forrás: saját adatfelvétel.

\section{Bizalom - intézményi bizalom}

A különféle kutatások általában hasonló változókra bontják az intézményi bizalom elemeit; az itt bemutatott kérdőív az ESS kérdéssorát használta:

Kérem, mondja meg, hogy Ön személy szerint mennyire bízik a következő intézményekben:

- a magyar országgyúlésben;

- a magyar jogrendszerben;

- a rendörségben;

- a politikusokban;

- a politikai pártokban;

- az Európai Parlamentben!

A válaszlehetőségeket itt is 0-tól 10-ig terjedő skálán adhatták meg a polgármesterek.

A legmagasabb bizalom a legkevésbé politikai jellegű szervezetek iránt tapasztalható (6. táblázat). A megkérdezett polgármesterek a rendőrségben bíznak leginkább, meglehetősen magas átlagértéket $(7,3)$ mutatva. Ezt követi a jogrendszer, majd alig lemaradva a már kifejezetten politikai intézmény, a magyar országgyủlés. A további szervezetek iránti bizalom egyértelműen alacsonynak tekinthető. Az Európai Parlament megítélése sokkal rosszabb, mint

6. táblázat: Az intézményi bizalom változóinak átlaga és szórása

Mean values and standard deviations of institutional trust among mayors and in the Hungarian society

\begin{tabular}{lcccc}
\hline \multirow{2}{*}{ Ön személy szerint mennyire bízik meg... } & \multicolumn{2}{c}{ Polgármesterek (N=137) } & \multicolumn{2}{c}{ Magyar lakosság (N=1614) } \\
\cline { 2 - 5 } & Átlag & Szórás & Átlag & Szórás \\
\hline ...a magyar országgyülésben? & 5,7 & 2,5 & 4,5 & 2,6 \\
...a magyar jogrendszerben? & 5,9 & 2,4 & 5,4 & 2,6 \\
...a rendőrségben? & 7,3 & 2,2 & 6,3 & 2,5 \\
...a politikusokban & 4,0 & 2,5 & 3,7 & 2,6 \\
...a politikai pártokban & 3,6 & 2,5 & 3,6 & 2,5 \\
...az Európai Parlamentben & 4,8 & 2,5 & 4,4 & 2,5 \\
\hline
\end{tabular}

Forrás: saját adatfelvétel, illetve az ESS 8. hulláma. 
a magyar parlamenté. A politikusokba és politikai pártokba vetett bizalom alacsony átlagértékei meglepőek, hiszen a polgármesterek is politikusok.

A polgármesterek válaszait az ESS 2016-os lakossági adatfelvételének eredményeivel összehasonlítva azt látjuk, hogy a településvezetők intézményi bizalma szinte mindegyik kategóriában valamivel magasabb, mint a lakosságé. A lakosság esetében az intézmények sorrendje megegyezik a polgármesterekével: a rendőrségbe vetett bizalom a legerősebb, bár ez az átlagérték jelentősen elmarad a polgármesteri értéktől. A két minta közötti érdemi különbség a magyar országgyűlés megítélésében mutatkozik. Míg a polgármestereknek jóval nagyobb a bizalma a magyar parlament, mint a többi politikai jellegủ intézmény iránt, addig a lakosság az európai és a hazai parlamentet egyformán negatívan ítéli meg, és nem sokkal pozitívabban, mint az utolsó két helyet elfoglaló politikusokat, illetve a politikai pártokat. Figyelemre méltó, hogy a politikai pártok iránti kifejezetten alacsony bizalomértékek között nincs különbség a két mintában.

\section{Bizalom - intézményesített partikuláris bizalom}

Jelen dolgozat a pozíciós bizalom tartalmán kissé változtatott, ezért intézményesített partikuláris bizalomként nevezi meg. A kérdőívben megtudakoltuk, hogy a településvezetők mennyire bíznak meg az adott kategóriába tartozó személyes ismerőseikben. ${ }^{10}$

Mennyire bizik meg a felsorolt kategóriákba tartozó személyes ismerőseiben, akik

- vezetö beosztású személyes ismerősök a politikában?

- vezetö beosztású személyes ismerősök a közigazgatásban?

- vezetö beosztású személyes ismerősök a szakigazgatásban?

- vezetö beosztású személyes ismerősök projekt- vagy pályázati szervezetekben?

- vezetö beosztású személyes ismerősök szakmai érdekképviseletekben?

- vezetö beosztású személyes ismerősök pénzintézeteknél?

- vezetö beosztású személyes ismerősök nagyvállalatoknál?

- vezetö beosztású személyes ismerősök egyetemeken vagy kutatóintézetekben?

A válaszlehetőségeket - a szokásos módon és tartalommal - 0-tól 10-ig terjedő skálán adhatta meg a válaszadó.

A 7. táblázatban szereplő átlagértékek mindegyik kategóriában magasabbak, mint a korábban vizsgált intézményi bizalom mutatói. Jelentős különbséget láthatunk az intézményi bizalomnál vizsgált nem személyes ismerős politikusok és a személyes ismerős politikusok iránt tanúsított bizalom mértékében. Az intézményesített partikuláris bizalmat mérő kategóriák között a politikusok átlagértéke azonban még így is a legalacsonyabb, az összes többi intézményi kategóriába tartozó ismerősben jobban bíznak a megkérdezett polgármesterek. 
7. táblázat: Az intézményesített interperszonális bizalom változóinak átlaga és szórása Mean values and standard deviations of institutionalized interpersonal trust

\begin{tabular}{lccc}
\hline \multicolumn{1}{c}{ Kategóriák } & Átlag & Szórás & \multicolumn{1}{c}{$N$} \\
\hline Vezető beosztású személyes ismerösök a politikában & 6,9 & 2,4 & 112 \\
Vezető beosztású személyes ismerösök a közigazgatásban & 7,6 & 2,0 & 122 \\
Vezető beosztású személyes ismerősök a szakigazgatásban & 8,0 & 1,9 & 94 \\
Vezető beosztású személyes ismerősök projekt/pályázati szervezetekben & 8,2 & 1,8 & 102 \\
Vezető beosztású személyes ismerősök szakmai érdekképviseletekben & 7,3 & 2,4 & 82 \\
Vezető beosztású személyes ismerősök pénzintézeteknél & 8,2 & 2,0 & 117 \\
Vezető beosztású személyes ismerősök nagyvállalatoknál & 7,8 & 1,7 & 95 \\
Vezető beosztású személyes ismerősök egyetemeken vagy kutatóintézeteknél & 8,5 & 1,6 & 76 \\
\hline
\end{tabular}

Forrás: saját adatfelvétel.

\section{A bizalom különböző formáinak összehasonlítása}

Az eddig bemutatott bizalomtípusok eredményeit összesítve elmondható, hogy a sajátos magyarországi (kelet-európai) bizalommintázat egyértelműen megjelenik a kistelepülési polgármesterek válaszaiban (1. ábra). A három, hagyományosan vizsgált bizalomforma (partikuláris és általánosított interperszonális bizalom, valamint az intézményi bizalom) közül a partikuláris bizalomhoz tartozó változók sokkal magasabb átlagértékeket mutatnak, mint az általánosított, illetve az intézményi bizalomhoz tartozók. E képet csak a rendőrség megítélése

1. ábra: A négy bizalomtípushoz tartozó változók átlagértékeinek sorrendje Mean values of variables of the four trust indicators

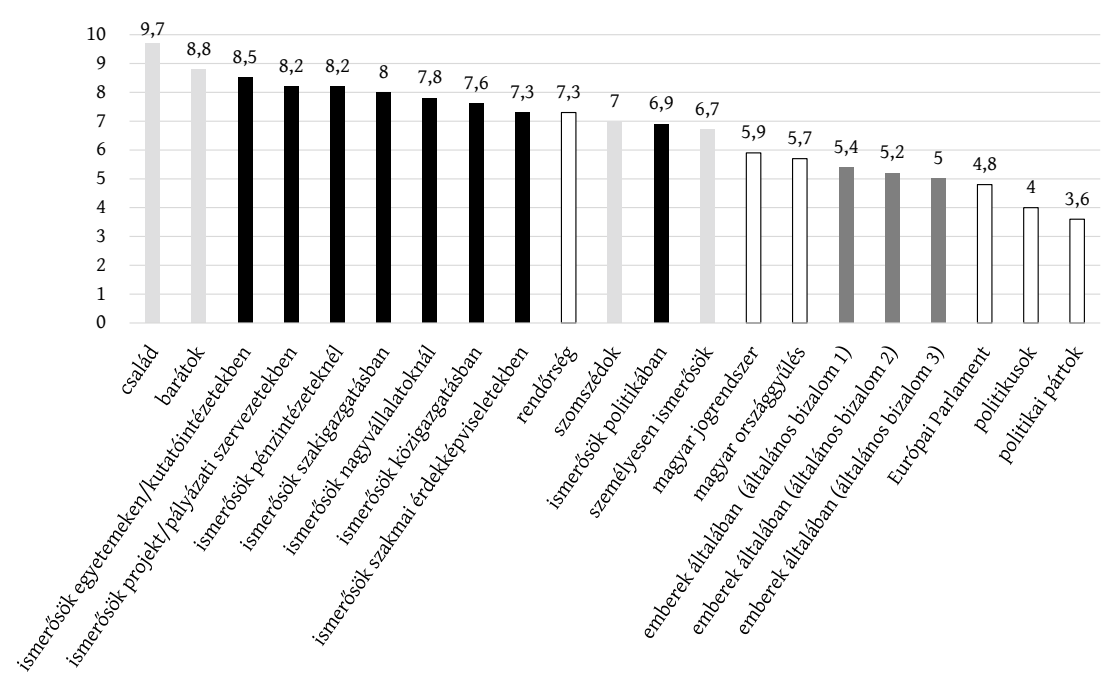

Forrás: saját adatfelvétel. 
miatt kell árnyalni, mely iránt igen nagy bizalommal vannak a polgármesterek, meghaladva ezzel a partikuláris bizalom mérésére használt két változó értékét. A partikuláris bizalom elemeinek elválása az általánosított bizalomtól a szük bizalmi rádiusz egyértelmű jele. A család és a barátok kitüntetett szerepe miatt az amorális familizmus és az informalitás kóros előfordulása a polgármesteri válaszokban is tetten érhetö.

Az informalitás jeleként értelmezhető az is, hogy a részint újonnan bevezetett intézményesített partikulárisbizalom-változó minden eleme jelentősen magasabb értéket mutat, mint az intézményi bizalom összetevői (a rendőrség kivételével). Vagyis az intézmények megbízhatóbbnak tünnek, ha személyes, ismerősi kapcsolatok segítik az ügyintézést, együttműködést. E fö összefüggések még világosabban láthatók a négy bizalomtípus összevont indexei alapján: a partikuláris bizalom 8-as és az intézményesített interperszonális bizalom 7,7-es értékével az intézményi és az általánosított bizalom 5,2-es értékei állnak szemben. ${ }^{11}$

\section{A kapcsolatok és a bizalom összefüggése - következtetések}

A problémafelvetés hipotéziseinek statisztikai vizsgálata (lineáris regresszió) zárja a tanulmányt. A modellekben függő változóként a kapcsolatok kiterjedtsége (számossága és diverzitása) szerepelt annak érdekében, hogy a különböző bizalomtípusokkal való összefüggést vizsgálni lehessen. A bizalom változói ${ }^{12}$ mellett az életkor és az iskolai végzettség is magyarázó változókként szerepelnek, hogy esetleges hatásaikat ki lehessen szürni.

Számításaink igazolják az előzetes hipotéziseket (8. táblázat). Mindkét modell esetében az általánosított bizalomnak nincs szignifikáns hatása a kapcsolatokra, ugyanakkor a partikuláris bizalomnak van: minél magasabb a polgár-

8. táblázat: A kapcsolatokra ható tényezők ( $N=137)$

Regression models on personal relations ( $N=137)$

\begin{tabular}{lcc}
\hline \multicolumn{1}{c}{ Mutatók } & A kapcsolatok számossága & A kapcsolatok diverzitása \\
\hline $\mathrm{R}^{2}$ & 0,124 & 0,085 \\
Korrigált $\mathrm{R}^{2}$ & 0,090 & 0,050 \\
$\mathrm{~F}$ & $3,635^{* * *}$ & $2,406^{* *}$ \\
Életkor & nem szignifikáns & nem szignifikáns \\
Iskolai végzettség & $0,201^{* *}$ & nem szignifikáns \\
Általánosított bizalom & nem szignifikáns & nem szignifikáns \\
Partikuláris bizalom & $0,288^{* * *}$ & 0,214 \\
Intézményi bizalom & $-0,224^{* *}$ & nem szignifikáns \\
\hline
\end{tabular}

Megjegyzés: ${ }^{*}<<0,1 ;{ }^{* *} p<0,05 ;{ }^{* * *} p<0,01$.

Forrás: saját adatfelvétel. 
mester személyes ismerősök iránt érzett bizalma, annál kiterjedtebb kapcsolati erőforrásokkal rendelkezik. Az intézményi bizalom esetében csak az első modell mutat szignifikáns eredményt, ez azonban megerősíti azt a feltevésünket, miszerint az intézményi bizalom negatívan befolyásolja a kapcsolathálózat kiterjedtségét, vagyis azok rendelkeznek több személyes kapcsolattal, akik kevésbé bíznak az intézményekben. Tehát azon polgármestereknek, akiknek nagyobb a partikuláris bizalma, több és diverzifikáltabb, tehát kiterjedtebb kapcsolatai vannak a tisztségükhöz köthető legfontosabb területeken dolgozó felső vezetőkkel.

Az empirikus eredményeket tárgyaló rész első felében a polgármesterek kapcsolathálózatát térképeztük fel. A megkérdezettek többsége viszonylag sok kapcsolati kategóriában rendelkezik személyes ismerőssel, főként a politika, a közigazgatás és a gazdaság területein, vagyis a magas státuszú pozíciók elérése a legtöbb polgármester számára megoldott.

Az elméleti bevezetésben leírtuk, hogy a bizalom típusainak kedvezőtlen kombinációja esetén a kapcsolati erőforrások negatív következményekkel járhatnak. A polgármesterek körében végzett felmérésünk alapvetöen tükrözi a magyar társadalom egészére jellemző bizalomsajátosságokat, melynek legfontosabb ismérve a partikuláris és az általánosított interperszonális bizalom kiegyensúlyozatlansága, illetve az intézményi bizalom alacsony szintje.

Az elemzés utolsó részében bemutatott magyarázó modellek megerősítik azt a feltételezést, miszerint a vizsgált kistelepülési polgármesterek esetében is fennáll a magyar társadalomra általában jellemző informalitás és kapcsolatérzékenység: a kapcsolatok és a bizalom között van ugyan összefüggés, de kizárólag a kapcsolatok és a partikuláris bizalom vonatkozásában, ami szük körü, be- és elzárkózó, klikkszerü együttmúködésekre utal. Az instrumentálisan kezelt kapcsolatok a kistelepülési polgármesterek viszonyrendszereit, cselekvéseit is mélyen átitatják. Mivel a polgármesterek kivételes pozíciójukból következően érdemi hatással vannak a helyi hatalomgyakorlásra, a lokális kormányzási stílusra, a helyi együttműködések és partnerségek belső mechanizmusaira és dinamikáira, így az informalitás eshetőségét elméleti feltevésként a tágabb települési érintkezésekre is vonatkoztathatjuk.

Jelen dolgozat éppen erre kívánt vállalkozni: egyrészt a társadalmitőkekoncepciót felhasználva elméletileg érveltünk amellett, hogy az informalitás általánosabb, absztrakt formájában miként ragadható meg, másrészt empirikus vizsgálattal igazoltuk az elméleti feltevéseket. Jelen munka következtetései további kiegészítő vizsgálatokat igényelnek a megalapozottság erősítésére, az irányvonal azonban biztatónak tünik. 


\section{Jegyzetek}

1 A kérdőív személyes lekérdezése az MTA KRTK RKI Dunántúli Tudományos Osztálya és a Pécsi Tudományegyetem Szociológia Tanszékének együttműködésében valósult meg 2017 áprilisa és júniusa között.

2 A minta meghatározása figyelemmel volt a megyén belüli járási eloszlásra, valamint a településnagyság-kategóriákra (100 fö alatti lakosságszámú települések, 100-200fő közötti, 200-500 fó közötti, és 500-1000 lakossal rendelkező települések).

3 A lényegesen diverzifikáltabb civil szektor e lekérdezésből kimaradt, s csak egy későbbi, kiterjesztett tárgyú és célcsoportú felmérésben vettük fel a kérdőívbe.

4 A mintából törölt esetek - kiugró értékeik miatt. A kiugró értékeket e kérdés itemjeinek összesítése alapján állapítottuk meg. Az extrém módon kiugró értékeket töröltük, vagyis azokat, ahol a nyolc item alapján a kapcsolatok száma meghaladta a kvartilis terjedelemnek a mediántól számított háromszorosát.

5 A három kérdés közül az első tekinthető az általánosított bizalom klasszikus kérdésének, ezt már több mint fél évszázada használják a kérdőíves vizsgálatokban. A másik két kérdést is gyakran alkalmazzák az első kiegészítéseként (Uslaner 2002).

6 Az ESS egy nemzetközi összehasonlító vizsgálat, amely 2001-től kétévente az európai társadalmak demográfiai jellegzetességeiről, politikai és közéleti preferenciáiról, illetve különféle társadalmi értékekről és attitűdökről nyújt adatokat.

7 Az első kérdés esetében 23 ország közül Magyarország a 19. helyet foglalta el az ESS 8. hullámának adatai alapján.

8 A WVS az ESS-hez hasonló nemzetközi összehasonlító vizsgálat, mely több évtizedes múltra tekint vissza. Az empirikus felmérés elméleti hátterét Ronald Inglehart értékelmélete adja (Inglehart et al. 2004).

9 A WVS 2009-es adatai alapján a család esetében a válaszadók 98,4\%-a választotta a „teljesen megbízik”, illetve a „valamennyire megbízik” kategóriát. A szomszédoknál ugyanez az arány $82,2 \%$, míg a személyes ismerősök esetében $86,5 \%$. Az eredmények tehát igen hasonlóak.

10 Akinek egy adott kategóriában egyáltalán nincs személyes ismerőse, annak a bizalmát természetesen nem lehet mérni.

11 A méréssel foglalkozó irodalomban gyakran éri kritika az összetett mutatók használatát az interperszonális és az intézményi bizalom tekintetében, mégis tudományos konszenzus alakult ki ezek alkalmazhatóságáról (pl. Boda, Medve-Bálint 2012; Uslaner 2002). Mintánkban a belső konzisztenciát mérő Cronbach-féle alfa mindegyik esetben megfelelő (általánosított bizalom: 0,83; partikuláris bizalom: 0,68; intézményi bizalom: 0,86; intézményesített interperszonális bizalom: 0,92).

12 A modellekben a fentebb bemutatott bizalomtípusok közül az intézményesített interperszonális bizalom változóját nem szerepeltettük.

\section{Köszönetnyilvánítás}

Bodor Ákos munkája az NKFIH által támogatott A bizalom és kormányzás összefüggései helyi szinten c. kutatás része (a 116424 számú projekt a Nemzeti Kutatási Fejlesztési és Innovációs Alapból biztosított támogatással, a K15 pályázati program finanszírozásában valósult meg). Grünhut Zoltán munkája része a PTE FIKP projektjének: A kutatást az Emberi Erőforrások Minisztériumának Felsőoktatási Intézményi Kiválósági Programja finanszírozta, a Pécsi Tudományegyetem 4. tématerületi „A hazai vállalatok szerepének növelése a nemzet újraiparosításában” programja keretében (a szerződés száma: 20765-3/2018/FEKUTSTRAT). 


\section{Irodalom}

Banfield, E. (1958): The moral basis of a backward society. New York State University, New York

Barber, B. (1983): The logic and limits of trust. Rutgers University Press, New Brunswick

Beck, U. (2003): A kockázat-társadalom. Út egy másik modernitásba. Századvég, Budapest

Beluszky P., Sikos T. T. (2007): Változó falvaink. Magyarország falutípusai az ezredfordulón. MTA Társadalomkutató Központ, Budapest

Boda Zs., Medve-Bálint G. (2012): Intézményi bizalom a régi és az új demokráciákban. Politikatudományi Szemle, 2., 27-54.

Boda Zs., Medve-Bálint G. (2013): Intézményi bizalomról nemzetközi összehasonlításban. In: Boda Zs. (szerk.): Legitimitás, bizalom, együttmúködés. Kollektív cselekvés a politikában. Argumentum, Budapest, 135-150.

Bódi F., Bőhm A. (2000): Sikeres helyi társadalmak Magyarországon. Agroinform Kiadóház, Budapest

Bodor, Á., Grünhut, Z., Horeczki, R. (2014): Socio-cultural cleavages in Europe. Regional Statistics, 2., 107-125. http://doi.org/c47c

Bognár L., Csizmady A. (2005): A falvak helyzete - közhangulat falun. In: Bognár L., Csizmady A., Tamás P., Tibori T. (szerk.): Nemzetfelfogások - Falupolitikák. Új Mandátum Kiadó, MTA SZKI, Budapest, 36-41.

Bourdieu, P. (1986): The forms of capital. In: Richardson, J. (ed.): Handbook of theory and research for the sociology of education. Greenwood, New York, 241-258.

Coleman, J. S. (1988): Social capital in the creation of human capital. American Journal of Sociology, 94. 95-121.

Coleman, J. S. (1990): Foundations of social theory. Harvard University Press, Cambridge

Csurgó B. (2011): Vidéken lakni és vidéken élni. Socio.hu, 2., 35-47.

Fukuyama, F. (1997a): Social capital. The Tanner Lectures on human values. Oxford University Press, Oxford

Fukuyama, F. (1997b): Bizalom. Európa, Budapest

Giczi J., Sik E. (2009): Bizalom, társadalmi tőke, intézményi kötődés. In: Tóth I. Gy. (szerk.): TÁRKI Európai Társadalmi Jelentés 2009. TÁRKI, Budapest, 65-84.

Giddens, A. (1990): The consequences of modernity. Polity Press, Cambridge

Granovetter, M. (1983): The strength of weak ties: A network theory revisited. Sociological Theory, 1., 201-233. http://doi.org/dxd8fx

Hajdu G. (2012): Bizalom, normakövetés és társadalmi részvétel Magyarországon a rendszerváltás után. In Kovách I., Dupcsik Cs., P. Tóth T., Takács J. (szerk.): Társadalmi integráció a jelenkori Magyarországon. MTA Társadalomtudományi Kutatóközpont, Argumentum, Budapest, 45-63.

Hardin, R. (2002): Trust and trustworthiness. Russell Sage Foundation, New York

Hardin, R. (2006): Trust. Polity Press, Cambridge

Inglehart, R., Basanez, M., Diez-Medrano, J., Halman, L., Luijkx, R. (eds.) (2004): Human beliefs and values: A cross-cultural sourcebook based on the 1999-2002 values surveys. Siglo XXI, Mexico City

Kovách I. (2013): A jelenkori magyar vidéki társadalom szerkezeti és hatalmi változásai. Hitel, 2., $145-187$.

Kmetty Z., Koltai J. A. (2015): Kapcsolathálózatok mérése - elméleti és gyakorlati dilemmák, lehetöségek. Socio.hu, 4., 34-49. http://doi.org/c47d

Letenyei L. (2005): Településkutatás. A települési és térségi tervezés társadalomtudományos alapozása. L’Harmattan, Ráció Kiadó, Budapest

Lin, N.(1991): Társadalmi erőforrások és társadalmi mobilitás: a státuselérés strukturális elmélete. In: Angelusz R., Tardos R. (szerk.): Társadalmak rejtett hálózata. MKI, Budapest, 23-49.

Lin, N. (2000): Inequality in social capital. Contemporary Sociology, 6., 785-795.

Lin, N. (2001): Social capital: A theory of structure and action. Cambridge University Press, London

Lin, N., Dumin, M. (1986) Access to occupations through social ties. Social Networks, 4., 365-385. http://doi.org/fvsp5f

Ludescher G. (2010): A vállalkozások és közösségek szerepe a rurális térségek megújulásában. Publikon Kiadó, Pécs 
Luhmann, N. (1979): Trust and power. John Wiley, New York

Pálné Kovács I. (2008): Helyi kormányzás Magyarországon. Dialóg Campus Kiadó, Budapest, Pécs

Portes, A. (1998): Social capital: Its origins and application in modern sociology. Annual Reviews of Sociology, 24., 1-24. http://doi.org/cmmcsz

Putnam, R. D. (2000): Bowling alone: The collapse and revival of American community. Simon \& Schuster, New York

Ragadics T. (2010): Kistelepülési önkormányzatok a társadalom peremén. In: Kákai L. (szerk.): 20 évesek az önkormányzatok: születésnap vagy halotti tor? Publikon Kiadó, Pécs, 609-616.

Ragadics T. (2015): Helyi társadalom, lokális közösségek az ormánsági kistelepüléseken. Doktori értekezés. PTE Interdiszciplináris Doktori Iskola, Pécs. http://www.idi.btk.pte.hu/a-kormanyzasteruleti-torteneti-es-tarsadalmi-dimenzioi-disszertaciok (Letöltés: 2018. augusztus 11.)

Seligman, A. (2000): The problem of trust. Princeton University Press, Princeton

Sik E. (2012): A kapcsolati tóke szociológiája. ELTE Eötvös Kiadó, Budapest

Sztompka, P. (1999): Trust: A sociological theory. Cambridge University Press, Cambridge

Táll É. (szerk.) (1995): Polgármesterek túl az eufórián. MTA PTI, Budapest

Táll É. (szerk.) (2000): Az új demokrácia önkormányzati vezetői. MTA PTI, Budapest

Tamás V. (2009): Polgármesterek kormányzási stílusa Magyarországon. Politikatudományi Szemle, 3. $132-154$

Tamás V. (2014): Politikai élet a helyi önkormányzatokban. MTA TK, Budapest

Tóth I. Gy. (2009): Bizalomhiány, normazavarok, igazságtalanságérzet és paternalizmus a magyar társadalom értékszerkezetében. TÁRKI, Budapest

Uslaner, E. (2002): The moral foundations of trust. Cambridge University Press, Cambridge

Váradi M. M. (szerk.) (2008): Kistelepülések lépéskényszerben. Új Mandátum Kiadó, Budapest

Varga Gy. (2005): Sokszínű falu - változóban. In: Bognár L., Csizmady A., Tamás P., Tibori T. (szerk.): Nemzetfelfogások - Falupolitikák. Új Mandátum Kiadó, MTA SZKI, Budapest, 59-73. 